\title{
Azanian Political Thought and the Undoing of South African Knowledges
}

\author{
Joel Modiri
}

[W] hat becomes possible when blackness wonders and wanders in the world, heeding the ethical mandate to challenge our thinking, to release the imagination, and to welcome the end of the world as we know it, that is, decolonization, which is the only proper name for justice [?]

Denise Ferreira da Silva (2018: 22)

Abstract: This article sets out a few key questions, themes, and problems animating an Azanian social and political philosophy, with specific reference to the radical promise of undoing South African disciplinary knowledges. The article is made up of two parts: The first part discusses the epistemic and political forces arrayed against black radical thought in South Africa and beyond. A few current trends of anti-black thinking - liberal racism, Left Eurocentrism, and postcolonial post-racialism - which pose challenges for the legibility of Azanian critique are outlined. Part two constructs an exposition and synthesis of key tenets of Azanian thinking elaborated upon under three signs: 'South Africa', 'race and racism', and 'Africa'. The aim of the discussion is to illustrate the critical, emancipatory potential of Azanian thought and its radical incommensurability with dominant strands of scholarship in the human and social sciences today. The article ultimately defends the reassertion of black radical thought in the South African academy today and underscores in particular the abolitionist drive of Azanian political thought.

Keywords: abolition, Azania, black radicalism, decolonisation, race 
My aim in this article is to adumbrate some of the key questions, themes, and problems that could animate an Azanian social and political philosophy - and by extension an Azanian jurisprudence in the current post-1994 conjuncture. I recall the Azanian political and intellectual tradition in order to restage its fundamental opposition to the political imaginary and vision of the Charterist or Congress tradition (of the ruling African National Congress [ANC] and its allied political formations and intellectual traditions) which ultimately shaped and determined the making of the post-1994 legal, political, and social order. Yet, the true radical challenge of the long Azanian tradition lies not in its critique of the negotiated settlement and post-1994 constitutional democracy but rather in its contestation of the very idea of 'South Africa'. 'Azania', after all, was developed precisely as the political, cultural, and ethical antithesis to the racist polity of 'South Africa' as constituted by the powers of settler-colonial white supremacy.

The provenance of the term Azania is a long and protean one, but for our purposes it served as a political and philosophical signifier introduced by the Pan-Africanist Congress and then adopted also by the Black Consciousness Movement as the true and liberated name for the territory currently mapped as 'South Africa' (Dladla 2018: 2-7). It is a key term in the lexicon of the Africanist-black radical tradition because it reflects the view of 'South Africa' as an artefact of colonial sovereignty that came into being in 1910 through the racial contract between the two European conquering powers that had subjugated the indigenous African population and other oppressed groups and racialised them as 'Blacks' in the process of inventing the political category of whiteness. ${ }^{1}$ Azania marks the repudiation of the settler-colonial foundations of 'South Africa' and beckons a post-conquest rather than merely post-apartheid society. ${ }^{2}$ In historical terms, then, Azania is a placeholder for a long-standing emancipatory and abolitionist horizon first articulated by Africans through the waging of wars of resistance against colonial rule. ${ }^{3}$

Perhaps because of its marking out of 'South Africa' itself as the fundamental problem for human liberation and justice, the Azanian tradition has been the object of much historical silencing and repression. Among the discontinuous mix of powerful rationalities, and conceits that led to the eclipsing of Azanian tradition (and with it, any serious articulations of black radical thought in 'South 
Africa'), I would speculatively identify the following: the ubiquitous valorisation of Western values, institutions, and knowledges; taken-for-granted assumptions about the solidity, naturalness, and permanence of the South African state; a hegemonic ANCcentred narrative of history and politics; and uncritical acceptance of liberal multiracialism and moderate politics as entrenched in the post-1994 constitutional order. Add to these the Eurocentric and ahistorical dismissals of African and black nationalisms as narrow, 'nativist', essentialist, reverse-racist, chauvinistic, victimological, atavistic, or in any case, unrealistic. ${ }^{4}$ Powerful currents of antiAfricanist, anti-decolonisation, and indeed anti-Black thought and practice have congealed over the past few decades in the systematic writing out of the narratives, actors, and ideas that make up the Azanian tradition. ${ }^{5}$

Yet this tradition endures in black political and cultural memory and has now returned more forcefully in public and academic discourse to register the reminder that the question of how to define the nation and constitute a political community - and the concomitant paradigms of law, justice, democracy and political ordering, culture and knowledge, and social and economic organisation - in the wake of colonial-apartheid, remain unsettled. The critical view that freedom and justice remain incomplete, outstanding, and unresolved problems or, put differently, that post-1994 legal and political rearrangements continue to reproduce and leave unaddressed the historical results of settler-colonialism, white supremacy, and racial capitalism is a key premise of an Azanian critique of the present. This critique implicates jurisprudence and, more specifically, the 1996 constitution to the extent that it secures the South African polity and preserves the racist foundations on which it was built under the guise of liberal democracy and through the ideological mystifications of 'transformation' and 'reconciliation' - both of which involve pragmatic accommodation of white interests and entitlements. ${ }^{6}$ It is significant that this failure to dismantle relations of conquest (i.e., the reproduction of racialised and classed conquered and conqueror social positions and subjectivities) was anticipated by Azanian intellectuals in their critique of the political ideology of the Congress tradition.

Through the protocols of an Azanian critical theory and critical jurisprudence, 'South Africa' is located and made legible to a 
repertoire of radical intellectual and political postures, including settler-colonial and indigenous studies, black radicalism and PanAfricanism, African philosophy, and critical race theory. ${ }^{7}$ While birthed in the historical conditions of colonisation and apartheid and resistance to them in 'South Africa', the Azanian tradition works within a continental Pan Africanist, transnational, and internationalist orbit of ideas and praxes and is marked by a five-fold itinerary: (1) the continuation and elaboration of the struggle for liberation at the analytical, intellectual, and conceptual level; (2) the critique and negation of Western civilisation - which is to say the dismantling of (settler-)coloniality, white supremacy, and racial capitalism (and the social, sexual, cultural-symbolic, intellectual, and political systems they engender and reproduce); (3) resolute analytic focus and consciousness about the ongoing constitutive material and symbolic force of race and racialisation; (4) a long view historical memory of colonisation, apartheid, their enduring structural violence, and their persisting afterlives in the post-1994 period; and (5) the restoration and reaffirmation of the political and cultural integrity of African, indigenous, and Black experiences and consciousness. ${ }^{8}$ Underpinning this itinerary is a procedure of writing and analysis that brings the concreteness, materiality, and urgency of the black condition, black suffering, and black resistance to the fore.

A more systematic recovery (but also reinterpretation and extension) of the Azanian tradition enables a disruption and reorganisation of the entire analytic territory in which 'South African' law, politics, and society have been thus far conceptualised, particularly in the context of the putatively 'new' South Africa. This article is only an opening provocation towards such reorganisation. I do not present the theory of the Azanian tradition here as exhaustive of the political pluriverse or without pitfalls and fissures. Rather the underlying argument of the article is that the critical visions of the Black men and women activist-intellectuals of the Azanian tradition contains searing and imaginative formulations of ethics and politics that can be drawn upon to contest the prevailing interpretations and hegemonic paradigms of social and political thought in 'South Africa' and the world today.

This article is made up of three parts. In the part that follows, I highlight the conceptual whiteness of the South African academy as a fundamental impediment to the legibility and development 
of an Azanian perspective in law, the humanities, and social sciences. Parts 3 and 4 sketch out in broad strokes some of the essential theoretical tenets and assumptions of Azanian social and political thought, with particular focus on the framing and conceptualisation of 'South Africa', race/racism, culture and epistemology, social change - and how these apply to the social realities of post-1994 South Africa. Part 4 also briefly spells out the relationship between Azanian thought and the abolitionist and decolonising critiques of the South African constitution and post-1994 jurisprudence.

The labour undertaken in this article is the work of theory-building with the aim of challenging and disrupting South African disciplinary knowledges, shaped as they are almost entirely from the standpoint of the conqueror's worldview(s). We recall the name and idea of 'Azania' not only to counter this standpoint but also to go beyond it and imagine a post-conquest, anti-racist, and pluralist society based on a culture of radical democracy and ubu-ntu (African humanness). ${ }^{9}$ In short, to think Azania is to rethink the fundamental premises of the present from the perspective of black radical memory and praxis.

\section{On the Conceptual Whiteness of the South African Academy}

Yet we cannot commence with this project of re-membering the Azanian tradition as a model of black radical critique without reckoning with and transforming the particular dynamics in the South African academy that have historically marginalised Black people and black thought. Critical investigations into the sociology and politics of knowledge have definitively refuted the notion of an objective, neutral, and perspective-less researcher and thereby dissolved the distinction or distance between researchers and their research techniques and findings. It is thus no longer controversial to argue that race and whiteness (and class, gender, and other significant markers of social positioning) are not merely objects of analysis and investigation but also structural factors that shape the approach, methods, conceptual vision, style, and conclusions of the researcher (Zuberi and Bonilla-Silva 2008: 18). 
Because white people constitute the socially dominant group in 'South Africa' and because this social dominance then manifests in white demographic overrepresentation in the academy, it is inevitable that a 'white ideological methodology', a set of 'white logic[s] and white methods', came to dominate and shape the 'canon' of the humanities and social sciences. ${ }^{10}$ This white ideological methodology - because it represents the worldview(s), perspectives, and background of whites - also corresponds to the actual racial interests of whites; interests undoubtedly threatened by radical calls for racial justice, decolonisation, and black liberation. It colours their analysis and imports 'white common sense' into the theoretical enterprise (Zuberi and Bonilla-Silva 2008: 21). The massive academic and scientific power that whites wield over higher education and knowledge production is characterised by a Eurocentric order of knowledge and a Northbound gaze (see Ramose 2000). Put another way, South African disciplinary knowledges (and knowledge about 'South Africa') and intellectual traditions have been constructed almost exclusively on the basis of a Euro-American canon. These knowledges and traditions (which shape teaching and research in the academy) derive their vocabulary, problems, criteria, methods, categories, and definitions from philosophical and scientific traditions born from and shaped by the cultural perspective and historical experience of colonial and imperial Europe. That this situation remains largely unchanged attests to the obduracy of historical conceits regarding Europe as the origin, centre, and driver of world history and consciousness and Western civilisation as the superior epistemological and cultural form across time and space.

We thus need to take seriously an insight derived from Tommy Curry that the over-determination of (South) African knowledges and intellectual practices by Eurocentrism and whiteness will not be resolved by seeking to establish an epistemological 'convergence' in terms of which Black political and cultural perspectives are granted the status of rigorous and legitimate knowledge only to the degree that they extend, reify, resemble, translate, analogise or converge with an established tradition of European philosophy (Curry 2011a: 320). In his writings on African-American studies, Curry has identified a 'methodological crisis' in Black thought caused by an overreliance on European-derived conceptual frameworks and European philosophical anthropology to theorise the experiences 
and realities of African-descended peoples (see Curry 2011b: 152). This methodological crisis for Curry inheres principally in widespread attempts by Black scholars to integrate the black experience and Black historical figures into the canons and categories of Western philosophy - whether for purposes of establishing the academic legitimacy and validity of Black thought, or for correcting the racism, ethnocentrism, and race-blindness of white philosophers (ibid.).

For Curry, while this has contributed to undermining the presumed universalism of Western thought, it has also rendered Black thought vulnerable to co-optation and de-radicalisation (ibid.: 152). His concern is that the practice of deploying blackness as a revision or supplement to European philosophical thought functions as a kind of racial therapy to placate white racial sensibilities in the academy and reduces Black thought to a mere application of white thought and black experience to raw material for white theory. In the end, this practice also fails to advance theory and knowledge that illuminates how Black communities themselves have culturally and politically understood their own historical condition and the nature of the societies and worlds they inhabit.

This is not unrelated also to the fact that nearly three decades since the formal end of Apartheid, we cannot speak confidently in 'South Africa' of a sustained tradition of Black intellectual practice - which is to say a self-consciously cultivated and reproduced tradition of analysis deriving its key questions, assumptions, methods, conceptual conventions, styles, and idioms from the authority of Black historical experiences and from the cosmology and cultural-linguistic resources of the African majority, practiced (institutionally and extra-institutionally) within an autonomous and organised community of interlocutors. The domination of the academy and knowledge production in general by white academics and the marginalisation of African and more broadly Black scholarship are two sides of the same coin, adhering precisely to the logic of bifurcation and elimination inherent to settler-colonialism.

In his 1998 inaugural lecture entitled 'When Does a Settler Become a Native?', Mahmood Mamdani argued that the Manichean divide between settler and native established through colonial conquest was not only political and social but intellectual as well. As he comments further on the South African academy, 'what 
is called African Studies was in reality a study of natives by settler intellectuals' (Mamdani 1998: 9). These 'settler intellectuals' comprised of both men and women, and they were also not simply right-wing or conservative but also included white liberal and left academics. According to Mamdani what these 'settler intellectuals' shared was a common horizon defined by racial power and white privilege: 'even when they empathized with the native, they believed the native to be incapable of self-consciousness' (ibid.: 9). Whereas earlier, more conservative, traditions of scholarship viewed the native as the product of disadvantaged biology, more 'progressive' left and liberal traditions viewed the native as a product of disadvantaged history.

Mamdani's point must prompt us to collapse the distinction between white liberal and leftist scholarly postures and those of white conservatives by locating them all within the same hegemonic project of whiteness, Eurocentrism, and, unavoidably, racism. Whereas the white conservative tradition upheld the racist theory that Blacks are biologically and culturally inferior according to the standards of Europeans and European ways of life and viewed this inferiority to be generally irredeemable, white liberals and leftists differed from this position only insofar as they regarded Blacks as capable of overcoming their inferiority through Western education, civilisation, and refinement. ${ }^{11}$ Naturally, both traditions of white thought (conservative and left-liberal) resulted in modes of knowledge production that were not only alien to but parasitic upon the Black experience in 'South Africa'.

There is a further problem with the fact that knowledge production and intellectual and scientific practices across all disciplines (including law and jurisprudence) remains numerically, logically, and methodologically led and structured by whites in general. This white hegemony extends to the academic study and knowledge in areas such as equality, land and property, constitutionalism, memory, transitional justice, poverty, spatial justice, human rights and 'social justice', the historical and philosophical study of society, and critical theory/Marxism/post-structuralism. In this way, whites both derive massive psychic and undue socio-economic benefits and advantages from historical injustice and racial oppression, and they also usurp the power to control and define the terms for understanding and resolving the social contradictions engendered by that 
history of oppression. This white epistemic dominance works to define the intellectual problems of our time and set the agenda (i.e., construct the reality largely on the basis of Western paradigms that privilege socially white accounts of the world). Its most pernicious effect is the systematic social and cultural miseducation of Black students.

This to say that the anomalous overrepresentation of white academics in a Black majority African society is not merely a demographic problem (of representivity, employment equity, and diversity) but a conceptual one as well. It both indexes and obscures the fact of continuing unfreedom that defines South Africa's faulty transition. Through leadership of academic departments and course coordination, academic seniority, and decision-making power in matters of appointment and promotion, teaching and postgraduate supervision, conference organising and international collaborations, journal editing and peer-review, and citation practices, white academics reproduce the centrality of their own perspectives, police the boundaries of the disciplines, and wield the power to validate or invalidate the methods, assumptions, and problems that circulate the field. Predictably, this has placed many Black academics and postgraduate students in the disempowering position of having to reproduce, mimic, and parrot white scholarship and work within accepted paradigms and canons to gain academic employment and recognition. In this regard, this is a manifestation of cognitive domination, epistemic racism, and white supremacy in the area of knowledge production and poses problems for the legibility and development of emerging Black critique.

The whiteness of the South African academy will have to be addressed not only at the level of demographic transformation of South African academia but also through a thoroughgoing conceptual reworking of its basic epistemic assumptions and practices. For our purposes, the conceptual whiteness of the South African academy inheres most acutely in its failure to confront and analytically foreground race as a salient, foundational, and central category of social, political, and legal analysis. Tied to this failure is also: (1) lack of serious engagement with Black thought and the Black experience in 'South Africa' and beyond; (2) evasion of the constitutive and ongoing role of settler-colonial white supremacy and racial terror in shaping social relations and dominant thought structures; 
and (3) routine epistemic and institutional violence against critical Black voices. ${ }^{12}$ This is despite the fact that race was the central logic and primary antagonism in the emergence and constitution of the modern world, ${ }^{13}$ and even more so in the making and installation of colonialism, racial capitalism and apartheid in 'South Africa' (see Keegan 1996; Magubane 1996).

While primarily conceptual and intellectual, the widespread evasion and minimisation of race in 'South Africa' also has a powerful psycho-affective dimension underpinned, on the one hand, by guilt, anxiety, fear, melancholia, and fragility (primarily about the unsettling effect of radical race critique on the presence and power of white settler subject-positions) and, on the other hand, by a historical hostility across the political spectrum to black radicalism and race-consciousness (due to their intellectual and political unravelling of the Charterist social compact, multiracialism, liberal optimism, and the 1996 constitution) (Gerhart 1978: 159).

\section{Trends in Anti-Black-Thinking}

Three particular trends linking the conceptual whiteness of the South African academy and the paucity of black-centred race-critical scholarship need to be briefly discussed here.

The first, explained by Avery Gordon and Christopher Newfield under the heading of 'white philosophy', is a form of 'liberal racism' or white moderate politics that presents itself as opposed to racial discrimination and subjection while also rejecting raceconsciousness and downplaying the continuing significance of racism. In this way it upholds and defends systems and discourses that produce racialising and anti-black effects (Gordon and Newfield 1994: 737). In Gordon and Newfield's account, liberal racism does not explicitly rationalise racism but rather treats the political and intellectual categories for engaging racism (especially structural and institutional analyses developed by racialised groups themselves) as 'conceptual errors . . . politically troubling and intellectually flawed' (casting them either as politically divisive, totalising, 'identity politics' or as reverse-racism) (ibid.). Liberal racial thinking presents itself as grounded in reason and not in ideology or history - which is to say liberal progressive politics presents its 
view of race as the rational truth about race, disavowing its own positionality and investments (ibid.: 378 ).

Liberal racial thinking as described here also takes the form of postmodern/poststructuralist anti-foundationalism and its routine template (which is to say formulaic and a priori) ascriptions of Black political thought as 'essentialist'. It is not only that antiessentialism can also be anti-intellectual, even imperial, in its disqualification of new or silenced theoretical constructions but also that it ultimately relies on an unacknowledged Western definition of the self and subject (as not unitary and fixed) and imposes this definition as universal onto other communities whose conceptions of self, subject, and community are organised by a different cultural metaphysics and different historical conditions - such as, for example, a cosmology oriented concretely towards ancestors, spirits, and the natural world and a collective predicament necessitating the grounding of one's humanity through shared bonds of solidarity and identification (Gordon 2006: 16-19; Robinson 2015: 12-23).

The main idea behind this liberal racial thinking is to construct a moral equivalence between all uses of race and then to argue that less race-thinking, race-talk, and race-consciousness will in turn lessen racism. This involves 'replacing the race problem with the "race" problem'; that is, to redefine the problem not as historically entrenched structural racism as racialised groups assert but rather to depict anti-racist discourses and movements as the real problem (Gordon and Newfield 1994: 739-740; see also Furedi 1999). Antiracialism is privileged over anti-racism. ${ }^{14}$ This is most evident in how the bulk of scholarship on race in 'South Africa' tends to focus on the theoretical deconstruction of racial categories and identities rather than being directed towards a critical analysis and dismantling of institutional, structural, and epistemic racism. The problem of liberal racial thinking also appears paradoxically in the choice among some Black decolonisation scholars - following theorists such as Achille Mbembe and Anthony Appiah - to expend extensive intellectual and professional labour positioning themselves aggressively against what they refer to derisively as 'nativism' and '(black) nationalism'.

The second trend is discussed by Suren Pillay in a critical interrogation of the privileging of 'deracialisation' over 'decolonisation' in the dominant discourses of knowledge transformation in post-1994 
'South Africa' (Pillay 2009: 235-267). Pillay surveys early debates on race and knowledge in the social sciences and humanities relating to the disproportionately white character of academic scholarship, including the 'radical' school of history-writing (deploying a social history Marxian reading of South African history). Through this discussion, Pillay details how the radical school of social historians (as prominent representatives of white leftist academia) supported a stark privileging of class over race as the basis for rewriting the humanities and social sciences in 'South Africa'. In so doing, according to Pillay, this critical tradition of white scholarship disarticulated race from colonialism, dissolved the historical problem of settler-colonialism, and effaced the ethical and political exigency of decolonisation (ibid.: 249). White radical historiography and white left politics in general effected a 'conceptual-historical dislocation of South Africa from the African narrative of colonialism into the Eurocentric narrative of capitalism'(ibid.: 250). As a result, 'South Africa' as an object of knowledge came to be disconnected from an apprehension of colonial continuity and then connected to a theoretical narrative driven by a European metropole. The origin story of this ostensibly radical turn in white scholarship has been traced to white liberal and left reaction to the Black Consciousness Movement's insistence on the centrality of race and racial power - an insistence which traumatically exposed white liberals and leftists as equally mired in the social and psychic dynamics of racial domination (see Webster 2018: 398-414).

Divergent analytic and historical starting points notwithstanding, the white leftist or critical/radical schools in the social sciences and humanities share the conceptual whiteness of liberal racial thinking in their theoretical displacement and conceptual relegation of race. It is a staggering fact that all of the major 'progressive' or 'critical' schools of thought circulating the academy can only imagine the experience of racially oppressed and colonised communities as invisible, peripheral, or supplementary. Whereas the bourgeois and imperial European Man is the site of liberalism; in Marxism, the European worker is the core revolutionary subject; for feminism, it is the situation of the heterosexual European woman that is the originary problem; and for post-structuralism, it is the post-war crisis of Western modernity writ large that animates its understanding of ethics, aesthetics, and politics. Whatever value these approaches 
have had in their South African articulations and elaborations, they have also played an unmistakable role in silencing and deforming how we understand and approach the problems of race, settlercolonialism, and white supremacy and the question of liberation and decolonisation today. The problematic of race, we might say, is the Achilles heel of all white thought and white politics.

The third trend is the subject of Jemima Pierre's critique of certain developments in African studies which produced a 'non-radical approach [to] the study of Africa' (Pierre 2013: 192) and enforced a powerful conceptual divide between the African continent and the African diaspora (ibid.: ch. 7). In one moment of her multi-layered analysis, Pierre relates how the post-1960s wave of African independence set in motion a shift in focus away from transnational anti-imperialist and anti-colonial projects and towards projects of nation-building. Consequently, in the absence of colonial administrations and white supremacist governments, struggles against racial oppression and white supremacy were understood to be primarily an issue for diasporic Blacks. While 'South Africa' could be seen as exceptional in this sense, since state-sanctioned racial oppression against the Black population was very much in full force in the 1960s, the problems Pierre identifies would nonetheless come to fruition in the post-1994 period. The overall point of Pierre's account is that within both academic disciplines and public discourse, the reality of postcolonial Africa (including 'post-apartheid South Africa') came under the false equation of formal political independence with self-determination, liberation, and nationalcultural sovereignty (ibid.: 193-194). The end of formal colonialism and apartheid as well as the assumption of government power by African elites silenced and took off the table critiques of neocolonialism and global white supremacy and eclipsed focus on the historical and ongoing 'interpellative reach of racialization' (ibid. 194).

Pierre shows how this development was shaped by the false assumption that flag independence ushered in an era for continental Africans in which race (while taken for granted) and its connections to white supremacy and imperialism were no longer primary concerns (ibid.: 187). The inward turn to national, local, and domestic concerns also led to a truncation in the understanding of race from the view of the Black Radical tradition (race as constitutive of the 
modern world) to a liberal view of racism as an anomalous feature of the liberal democratic state (ibid.: 192). In the context of post-1994 'South Africa', race also came to be seen as an 'internal impediment' to nation-building, 'reconciliation' and social cohesion - with the 1996 constitution (and the attendant discourses of rights, the rule of law and good governance) displacing the emancipatory frameworks and traditions of Black struggle as the marker and measure of political and social change. The effect of this inward turn was that the understanding of race in its 'global and interconnected structural dimensions' and a recognition of the 'coevality of African and the disapora' were lost or minimised in the academy, with the result that the general language, affect, and analysis of Pan-Africanism and Black radicalism also became marginal and derelict.

Bearing in mind the political economy of knowledge production and the racialised power relations that saturate South African higher education, it is clear that an increase in the ratio of black researchers in South Africa is a necessary but wholly insufficient condition for redressing this current state affairs. Dismantling the conceptual whiteness of the academy will require a new generation of oppositional Black academics to reset the terms of social, historical, political analysis through a sustained intellectual and political engagement with the global archive of liberatory Black thought. My argument in this article is that the Azanian tradition represents and enables precisely such a possibility for intellectual sovereignty and epistemic justice. A Black radical critique of post-1994 'South Africa', however, still enters inhospitable ground because it introduces a way of speaking and thinking about race and history that returns us all to the scene of the crime - the site of the interminable, irreparable, and unforgivable historical antagonism - and thus produces different forms of existential discomfort.

\section{Shades of Azanian Critique: Key Theoretical Tenets}

I now turn to sketch more systematically what I would describe as the key theoretical tenets of Azanian social and political thought. The account to follow is necessarily partial in two senses: first, it will only offer brief and broad strokes of each aspect of Azanian 
thinking; and secondly, it will reflect only one interpretation of a vast, fluid, contested, and continuous archive.

\section{(a) South Africa as an Unjust and Unethical Political Formation (Or: The Problem of South Africa is 'South Africa')}

The Azanian political tradition is distinguished from all other anti-colonial and anti-apartheid movements by its uncompromising, decolonising, and abolitionist orientation towards the South African colonial state form. The primary thesis and binding motif of Azanian thought is that 'South Africa' is an unjust and unethical political formation and axiomatically racist polity, predicated upon colonial conquest, slavery, and racial subjugation. The basic problem and fundamental injustice of 'South Africa' is thus not identified in its laws, practices, and excesses of discrimination, segregation, and violence but rather in its very founding as a European-created and European-dominated racial polity (Hallett 1974: 677) - a 'white dominion' or 'white man's country'. As a political construct, 'South Africa' was created without and against the conquered peoples within its political territory. The 'native' in this historical order was a 'mere subject of conquest', 'under the state but not a party of it' (Magubane 1996: 287, 306, [my emphasis]). Indeed, the 1910 Union of South Africa was the ultimate consolidation of European domination as it also signalled the final death knell for indigenous kingdoms and sovereignties and marked the loss by Africans of land, labour power, mineral wealth, cattle, selfknowledge, and sovereignty (Magubane 1996: xiv; Beinart 2001: 1-2). In this sense, the making of 'South Africa' - through the unification of its two European conquering powers (the Boers and the British) - constitutes a 'racial contract'; that is a (im)moral, political, economic and epistemological contract to found a polity on the basis of the principle and system of white supremacy (Mills 1997: 9-19; Hallet 1974: 664).

The formation of 'South Africa' as a settler-colony was built on a form of colonial governmentality which asserted the supremacy of Western civilisation, the necessity of white domination and Black subordination, and the need for native peoples to be destabilised, controlled, and governed. The political rationale was to preserve white settlement and avert insurrection and the economic rationale was mass proletarianisation and exploitation of Black labour. To 
be sure, both a political economy (racial capitalism) and a political ontology (antiblackness) are integral to the normative and structural violence of 'South Africa's' settler-colonial foundations. In particular, the disproportionate numerical superiority of the colonised African population and the resultant belief by the colonists that European domination had to be 'permanent' (Boahen 1990: 143) ${ }^{15}$ necessitated the practice of 'ultra-colonialism' (ibid.: 224), characterised by an 'extreme' mode of racial hierarchy and subjugation (ibid.: 208) in which indigenous alterity was to be neutralised and contained. Where one historical account describes the twentiethcentury entrenchment of racially based dominance and white power in the formation of the South African state as 'unique in its rigidity' and 'particularly uncompromising' (Beinart 2001: 3), another invokes its 'monstrous' and 'devastating' character (Magubane 1996: xii; 4). Thus, the historical record bears out that in order to institutionalise and maintain European supremacy and white settlement in 'South Africa', Africans and other political communities were subjected to perpetual and systematic inferiorisation at the level of their political status and human value. This negation of the humanity of colonised and racialised peoples was accompanied and reinforced by the entrenchment of colonial rule based on the political, legal, cultural and economic systems, practices, and ideas of Europe (Boahen 1990: 144-148).

The injury and injustice of colonisation did not only take place at the socio-economic and political levels but more profoundly also at the epistemic, metaphysical, and spiritual levels (Kelley 2017: 269; Comaroff 1998: 321-361). This was not primarily a will to only exclude, deprive, and discriminate against colonised peoples. Rather, the aim (incompletely realised, of course) was to colonise the being and consciousness of Africans by destroying their 'metaphysical and material relations ... to land, culture, spirit, and each other' (Kelley 2017: 269) and violently incorporating them into an alien life-world. Both a 'colonial state' and a 'state of colonisation' was imposed on African peoples and other racialised communities in the making of 'South Africa' (Comaroff 1998: 267). This in turn produced a psycho-political dynamic, which is to say a master-slave relation (and 'inferiority-superiority complex') primarily along the line of race, that structures the basic features of South African social relations and subject-positions. Put in other words, 
colonial conquest and its unfoldment in the twentieth-century making of 'South Africa' was a subject-producing process that invented and entrenched particular political identities - native and settler, Black and white - and organised and institutionalised these identities in a relentlessly bifurcated, hierarchical, and antagonistic relationship to one another through the mechanisms of political, legal, economic, and cultural power.

While it is important to note that the process sketched above is not static or linear but was constantly shifting, contingent, and remade to adjust to prevailing conditions, it is of equal importance to underscore the near absolutist civilisational logic of racial difference that underpinned and suffused it. Consequent to its invasion by two European conquering powers, the making of 'South Africa' features an uneven agglomeration of two competing racial ideologies or traditions of white supremacy. The Boers or Afrikaners (who descended from the first Dutch colonisers) represented the traditional variety of white supremacy, referred to as 'teleological racism' or 'racial naturalism', which posited the irredeemable, natural, and preordained inferiority of Black people and their fixed destiny as the servant-subjects of white people (Fredrickson 1981: 189-190; Goldberg 2002: 74-80). This version of colonial racism generally rejected any assertion of equality, parity, and coexistence between the African and the European as both unnatural by some divine or natural law and also as a major existential threat to the conservation of white power and identity. Accordingly, racial difference was principally regulated through segregation and extreme coercion. The British represented the more 'enlightened' and benign but no less violent ideology of 'evolutionary racism' or 'racial historicism' which instead viewed the civilisational immaturity and inferiority of the 'non-European' as mutable through gradual elevation into the norms of Western civilisation, education, and political economy (Frederickson 1981: 189-190; Goldberg 2002: 74-80). In this model of colonial racism, racial difference is implemented through trusteeship, assimilation, and gradual inclusion - and 'racial equality' is deemed possible (even desirable) but only in a manner that does not undermine the dominant social position of whites and the authoritative position of Western culture in determining the overall way of political, legal, cultural, and even private life in 'South Africa'. 
As settler ideologies, both traditions of racism are subtended by the 'right of conquest' - the assumption of the entitlement of whites to lord over their racial Others through disproportionate social, institutional, and economic power. The formation of 'South Africa' was made possible through the unification of the Boers and the English and their agreement to set aside their own intramural conflicts in order to protect their common interests of property and status against the native population. In this process, whiteness and white identity was produced and bonded together into a hegemonic group identity and national identity with a shared interest in maintaining white supremacy (Gerhart 1978: 22). ${ }^{16}$ At the same time, native and more broadly 'non-European' peoples were formally 'denationalised' and relegated to the status of non-belonging and non-being, imagined as outside of the borders of human and political community, legible only as (physical, sexual, psychic) labour in the realm of mere life.

For its colonialist architects, the overriding principle was that in order for 'South Africa' to exist, whites must be white (bearing unhindered political and legal status; socially, culturally, and economically dominant; autonomous and self-sufficient; insulated from vulnerability and violation; possessing an exponentially higher value and integrity of human life and standard of living; and symbolically and aesthetically metonymic with humanity) and Blacks must be black (racially subjugated; impaired political status and unsovereign; dependent and encumbered; generally locked in a wasted and abject social existence; fungible and disposable to power and violence; and exposed to ongoing psychic and cultural debasement) (for a psychoanalytical-cum-Fanonian rendering of this proposition, see Hudson 2013: 264). Rather than aberrational to the universalist and modernist potentiality of the South African state, racial domination, and antiblackness are intrinsic to its basic character and structure. Thus, the production of the multigenerational and virtually self-perpetuating socio-political and economic arrangements built on racial hierarchy as well as the long-enduring psycho-social traumas and Black cultural and spiritual alienation that defines 'South Africa's' pasts and presents are both the result and the afterlife of European colonial project.

From its mid-twentieth-century founding, the Azanian tradition in the form of the Congress Youth League of the 1940s set the 
foundation for repudiating the legitimacy of the colonial and apartheid state both in terms of its philosophical and historical analysis of the South African situation and in terms of its political mobilisation and praxis. The Youth League of the 1940s under the leadership of Anton Muziwakhe Lembede is notable for its radical break from the older generation of ANC intellectuals who followed a mode of African opposition to colonialism which equated progress for Africans with assimilation into white Western society and with the fulfilment of the promises of trusteeship and imperial citizenship (Gerhart 1978: 38; Soske 2018: 68, 77). This is a generation of westernised African elites (or 'amakholwa') who in important respects had acceded to their status as colonial subjects and fought for the equal opportunity of Africans to assimilate European culture, learn modern skills, and vindicate African competence (Gerhart 1978: 38). In such a set-up, 'the rights of whites to lead the way was generally assumed' (ibid.) and patient persuasion and racial cooperation, with Africans as 'junior partners', were the preferred strategies of change.

The emergence of the ideology of Africanism and the shift to a more militant political register as well as the new conditions and new possibilities of the 1940s marked a major displacement of this more conservative and assimilationist tradition in African politics (ibid.: 67; see also Ross 2008: 121). In this period, the politics of assimilation, cooperation with white power, gradual change, and moral suasion not only became obsolete but also were viewed as ethically and politically untenable by the young pioneers of Africanism. This was because in the Africanist philosophical and historical analysis, whites had no right or entitlement to rule over 'South African' land, peoples, and political territory (Gerhart 1978: 67). Such right belonged only to the African by reason of both indigeneity (or what Lembede referred to as 'the historical or even prehistorical position' of Africa as a 'Blackman's continent' (ibid.: 68 ) and numerical majority status. Working within a Black Marxist analytic, Bernard Magubane has added that the country also belongs to Africans 'through life-and-death labours extracted from them to build everything the settlers claim as their own' (Magubane 1986: 3). It also followed from this position that Africans were not merely a nation among nations within the borders of 'South Africa' but were the nation and were, in the language of the 1948 ANC Youth 
League Basic Policy, 'the rightful owners of the land' (Gerhart 1978: 68). In the Africanist view, therefore, South Africa as a political entity was 'illegitimate and void' both because it was predicated on dispossession and subjugation and because of its undemocratic and exclusionary foundations.

The Africanists adhered to a position of non-cooperation, noncompliance, and non-collaboration with the institutions of the colonial state (such as, at the time, representative councils and native administrative boards) (ibid.: 80) and with elite white organisations and bodies (ibid.: 75). Instead, they advocated for boycotts and turned to mass organisation and mobilisation and embarked upon programmes of radical political education towards self-determination, social and psychological emancipation, and national liberation (ibid.: 77, 80). This reflects a clear repudiation of the legitimacy of the colonial state and a formulation of anti-colonialism centred on a struggle for the reclamation of land and sovereignty and the recovery and reassertion of African being and culture. This stands in significant contrast to the historical striving of the Congress Tradition for civil and political rights, for belonging, inclusion, and recognition within the settler-created and settler-dominated social order, for access to the civilisational accoutrements and universalist promises of Western modernity, and for the (racial) democratisation of the colonial system (Soske 2018: 68-69). For the Africanists, such a striving could lead only to a dead-end.

The logical and necessary implications of this position were indeed 'revolutionary' in the sense that it would entail: (1) the remaking of African identities against tribalist and ethnic divisions as well as spiritual and cultural repair and transformation of those identities (Gerhart 1978: 61); (2) the total dismantling of white supremacy (and not its accommodation) (Sobukwe: 1959); (3) a fundamental change in the basic structure and governing values of South African society through a re-ordering of its political, economic, and cultural-intellectual systems and practices (Gerhart 1978: 68). Thus, from the earliest articulations of Africanism or Azanian political thought, abolition (emancipatory rupture) and decolonisation and not egalitarian reform (multiracial democratisation) of 'South Africa' is the core historical mission and ethicopolitical demand of the Black Radical Tradition. This abolitionist striving to terminate the constitutional and constitutive foundations 
of 'South Africa' flowed from the ethical and political convictions of the Azanian tradition as well as from their analytic hypothesis that 'South Africa' as an embodiment of settler-colonial white supremacy 'could not be reformed' (Tafira 2016: 302).

The political philosophy of the Azanian tradition upends standard descriptions of its movements and proponents under the oft-derided banner of 'nationalism'. We must in the first place take seriously the ethical, political, and historical distinction between European nationalism(s) (what we might call nationalisms of empire) and anti-colonial nationalisms (nationalisms of resistance) (Boahen 1990: 240). In the case of most European nationalisms, homogenous and mostly culturally and linguistically identical communities are bonded together in the search for sovereignty, independence, and oneness based on a correspondence between the cultural nation and the political state. In the context of Empire, this search often came with assertions of superiority and chauvinism expressed as anti-immigrant xenophobia, war, state racism, and domination of Othered communities and nations. Thus, nationalisms of empire conceive of the identity and geography of the nation-state in exclusionary terms, as closed and static. Anti-colonial nationalisms in Africa instead emanated from culturally and historically diverse groups working to forge new collective identities shaped by shared historical conditions (principally, the violent imposition of colonial modernity and alien rule as well as the vinidicationist imperative to make and claim their own worlds of meaning and value). It is in this sense that Adom Getachew has recently theorised anti-colonial projects in Africa as projects of world-making which reinvented concepts of sovereignty and self-determination beyond the nationstate through the assertion of a global vision of non-domination (See Getachew 2019). The same can be said about the political, historical, and ethical distinction between impositions of colonial sovereignty and demands for indigenous sovereignty.

The Africanists took the state form primarily as an object of critique and resistance. Throughout its development, Azanian thought was marked by a political geography that extended well beyond the borders of 'South Africa' to touch on the continent, the diaspora, and the Third World/Global South - a move that signals a clear rejection of artificial colonial borders (Tafira 2016: 297). We see this emerging in Lembede's definition of the African nation as 
encompassing Africans from the 'Mediterranean Sea in the North to the Indian and Atlantic Ocean in the South' (Fredrickson 1995: 280). In Sobukwe's 1959 Opening Address, which included statements on 'the international scene' and 'Afrika's position' within it, he integrates a critique of the machinations of Western imperialism with a denunciation of 'South African exceptionalism' - affirming that South Africa is 'an integral part of the indivisible whole that is Africa' (Sobukwe 1959). Indeed, the ultimate aim of Sobukwe's Africanism in particular was to incorporate the polity and territory now known as 'South Africa' into a United States of Africa (Fredrickson 1995: 285; Raboroko 1960: 29). National liberation and self-determination were thus only a first step in the struggle to decolonise and hence re-order the world (Getachew 2019: 1, 8). In this way, the Africanists posited a struggle over the nation which is not reducible to a simple nationalism in large part because they situated 'South Africa' in the historical problematic of European imperial expansion and identified strongly with continental and transnational Pan-Africanisms (Gerhart 1978: 201, 207). For his part, Biko would add an anti-imperialist, anti-capitalist internationalist outlook to this position by linking Black Consciousness to the global struggles of the 'Third World' (Biko 2012: 78). As Biko stated, 'the black-white power struggle in South Africa is but a microcosm of the global confrontation between the Third World and rich nations of the world' (ibid.). In their revolt against artificial colonial borders, alien rule, and white supremacy, the anti-colonial and race-conscious (inter-)nationalism of the Azanian tradition, its movements and thinkers, placed collective social organisation and the emancipatory refashioning of new subjects, new geographies, and new futures at their heart of their political visions.

\section{(b) A Black Radical Conception of Race/Racism}

If the colonialist conception and discourse of race asserts the existence of a natural (whether biological or civilisational) division of the human species into immutable and distinct racial types understood to bear homogenous and intrinsic traits and characteristics (Magubane 1996: 33-34), the Azanian conception of race neither reifies or conserves the idea of racial difference nor does it disavow the historicity and materiality of race. ${ }^{17}$ Instead, the colonialist discourse of race is countered by means of a critical, historically 
grounded, and emancipatory conception of race consistent with the historical and social theory of black radicalism and the now wellworn formulations of critical race theory. In such a conception, race is theorised in terms of the interplay of its political-historical, structural, and psycho-social elements.

In this theorisation, race is understood to originate from the Western racialisation of the world through European colonial invasion, conquest, and rule which by many accounts was set in motion by what Sylvia Wynter describes as the '1492 event' (Wynter 1995: 5-57) and unfolded on these shores from the 1652 arrival of the Dutch colonisers up to the nineteenth- and twentieth-century British imperial and, later, white supremacist rule. In this process, groups of human populations who knew themselves by other names and signs came to be marked by race - categorised and divided through metaphors of skin colour and reason generated from within European philosophical, socio-cultural, scientific, symbolic, and cognitive systems of representation (Wynter 1995: 5-57; Magubane 1996: 320; Ramose 2003: 544). Thus, it was in the colonial encounter that 'whiteness' and 'blackness' came into being as historical, symbolic, and material forms, and it was through conquest and racial subjugation that the historical categories and social positions of 'Black' and 'white' were produced and reproduced (Magubane 1996: 320-321). On this view, whiteness marks a position of historical dominance buoyed by fictions of ontological and epistemological superiority established and produced through colonisation. Blackness, on the other hand, represents both the negated antithesis of whiteness as well as the collective and ongoing resistance to it (ibid.).

This is to say that in the understanding of the Black Radical Tradition, race represents an ethical and political-historical category and marker of social and symbolic positioning originating from the power relationships and ideological systems established and produced through European domination, colonisation, and white supremacy. In Azanian thought specifically, this power relationship was generally expressed in the Manichean divide between conqueror and conquered, invader and invaded, and dispossessor and dispossessed (Gerhart 1978: 149). Rather than a pre-given and fixed fact about the human species rooted in pigmentation, biology, genetics, geography, and civilisation as the colonialist discourse variously posits, race is precisely a social and political relation of 
antagonism constructed through history via the ontological and epistemological mystifications of European colonisers and structured in a very complicated way primarily along two axes, namely that of 'white-nonwhite' (white supremacy) and 'Black-nonblack' (antiblackness). These axes span a spectrum of differently marked 'racial' groups whose value of humanity and material well-being corresponds to their relative proximity to whiteness and distance from blackness - the latter figured in the Racist Mind as the paradigmatic condition of racial Otherness in the modern world, the very ontological basement of humanity (Mills 1998: 76-77). The 'race myth' as the Africanists referred to it (Sobukwe 1959), fuses a false logic of biological and cultural difference with a vertically defined configuration of humanity that results in a 'complete rupture in the human family as it was divided into "inferior" and "superior" races' (Magubane 1996: 321). ${ }^{18}$

In the making of the colonial state of 'South Africa', race was the 'first principle' of social organisation and subject formation (Magubane 1996: 324) but always already articulated through norms of gender and sexuality, religion, ethnicity, and class structures. The white minority state that emerged from the 1910 Union of South Africa was predicated on the belief in the natural and necessary superiority of whites and constituted through the assembling of political, legal, cultural, educational, spatial, and social systems on the basis of this belief. Thus, racism acquired an objective material basis in the processes of land dispossession, slavery, racial proletarianisation and labour exploitation, political and legal exclusion, impairment of cultural and educational capabilities, and routinised contempt suffered albeit differentially by racially oppressed political communities (marked as 'non-whites') and in the maintenance of all white people's economic, social, political, and psychic interests. This is further wedded to an understanding of racism as a scene of intersubjective dehumanisation and a generator of profound psychological damage.

The archive of Azanian thought exhibits a deep appreciation for the interior (psychic, affective, and spiritual) life and mental conditioning and outlook of the colonised. The imposition of Western modernity based on European racial ideology and everyday white racism disfigures the psyche, consciousness, and self-esteem of the oppressed, producing spiritual, and cultural alienation which, when 
internalised, leads to further social dysfunctions, self-negation, passivity, and depersonalisation. From its initial development by Lembede, but also AP Mda and Jordan Ngubane, among others, the philosophy of Africanism targeted the condition of inferiorisation and dependence that had been imposed on Africans under colonial rule. Whether in the form of benevolent paternalism or brutal violence, racial domination generated among the colonised peoples a 'crippled and crippling psyche' (Gerhart 1978: 55), a 'debasing self-image' (ibid.), 'degeneracy and cultural confusion' (ibid.: 58) and ultimately a 'pathological state of mind' which manifested in 'abnormal ... phenomena' that included 'the worship and idolization of whitemen (sic), foreign leaders and ideologies' (ibid., citing 'Policy of the Congress Youth League' [May 1946]). This is why the intellectuals and activists of the Azanian tradition placed an overriding emphasis on 'psychological liberation', resisting forced 'Europeanization' of African cognition and consciousness and overcoming 'mental slavery' as central exigencies in the struggle against colonial racism (Tafira 2016: 297). In point of fact, the analysis of the Africanists was that the 'most vital frontier in the war for national liberation ... [was] the psychological frontier' (Gerhart 1978: 161).

Race, for the Africanists, has no real meaning outside of the historical and political context of its ideational fabrication and material (re)production, which is why in his opening address at the Inaugural Convention of the PAC, Sobukwe reiterated the (widely misunderstood) moral and scientific truism that 'there is only one race to which we all belong, and that is the human race' (Sobukwe 1959). This signified a direct repudiation of the colonialist 'myth of race' which was disseminated and mobilised by European imperialists and colonisers 'in order to facilitate their inhuman exploitation of the indigenous people of the land' (ibid.). It is on the basis of this critical and emancipatory reinterpretation of the materiality of race/ ism that the Africanists rejected two features of the racial discourse and politics of the Congress/Charterist Tradition, namely its commitment to multiracialism and its valorisation of 'good whites', both of which the Africanists viewed as an uncritical affirmation the colonialist discourse (and myth) of race. It is also on that basis that they argued against the protection of minority rights (Gerhart 1978: 195). Paradoxically, it is also why they were mistaken in 
denying the charge of being 'anti-white'. This latter proposition will be developed in more detail in future writing.

In their interventions on what is famously termed the 'National Question', the Africanists critiqued the 'multi-racial liberalism' that animated the Congress Movement and was ultimately encapsulated in the Freedom Charter (to later be taken up as the central motif of the United Democratic Front in the 1980s and of the 'rainbowist' constitutional dispensation of the 1990s) (see Dladla 2017: 101-127; Pillay 2015: 133-152). In the first place, multiracialism implies that 'there are such basic insuperable differences between the various "national groups" by compartmentalising those national groups into reified and impermeable racial identities and interests. For Sobukwe, this was 'racialism multiplied' and would only result in a 'kind of democratic apartheid' (Sobukwe 1959). In the second place, multiracialism, to use Sobukwe's words, 'panders to white interests' (ibid.); indeed it 'fosters and safeguards' them (Tafira 2016: 297, 301). The ruse of multiracialism as embodied in the Freedom Charter's famous declaration that 'South Africa belongs to all who live in it, black and white' lay in how it ultimately preserved the unequal relations of conquest by erasing the historical conditions of white power and presence and bypassing the settlercolonial foundations of 'South Africa'. (In this context, the fact that the Freedom Charter was in fact also predominantly conceptualised and drafted by non-Africans, and especially white leftists, surely added insult to injury). ${ }^{19}$ This failure to resolve the historical antagonism was seen by the Africanists as a device for perpetuating 'slavery under a new guise' and for promulgating a concept of nationhood in which 'the dispossessed and their dispossessors, the victims and their robbers - are all countrymen' (Raboroko 1960: 26). Thus, rather than dislodge the material and symbolic basis of the myth of race as the Africanists would have it, multiracialism seeks to manage (and thereby reify) race through accommodationist and egalitarian adjustments that nonetheless maintain the underlying political ontology that produced the categories and realities of blackness and whiteness in the first place.

Africanists such as Lembede generally considered multiracial collaboration and even racial reconciliation with 'good whites' untenable and impossible, since it was their view that whiteness is a position of unjust dominance predicated on negation, 
dehumanisation, and racism. In their view, all whites, irrespective of their political and social identifications, benefitted from white supremacy and had an objective material interest in the continuation of the colonial and apartheid status quo (Gerhart 1978: 70-71). Because whiteness and white supremacy are historically coeval and inseparable, the Africanists were of the view that 'no whites could ever work wholeheartedly for the total dismantling of the South African social order' without risking their long-term, fundamental interests (in whiteness and settler-colonialism) (ibid.: 154-155). Put simply, for the Africanists, the problem of 'good whites' was (and is) that they still want to be white.

As the chief theoretician of Black Consciousness, Biko would also draw upon, extend, and rework these themes of Africanist thinking on race through his theorisation of the historical and social reality of 'South Africa' under the signal concept of 'the totality of white power' (Biko 2012: 6, 66). 'Totality' in this instance could be read to signify the multidimensionality of white supremacy the fact that it spans across the legal, political, socio-economic, cultural, cognitive-epistemic, psychic-spiritual, somatic, and metaphysical realms of the human and Black experience - and as well as the range and reach of its terror and devastation across time and space (Mills 2003: 35 - 48). Biko's statement that 'the cardinal point [in Black Consciousness thought] is the existence in our society of white racism which has been institutionalised' (Biko 2012: 149); his references to 'white racism' as 'the problem' (ibid.: 25) and 'the real evil in our society' (ibid.) as well as his claim that 'colour' is 'the greatest determinant' of politics (ibid.: 54) suggests that Biko treats racism as the primary antagonism in the South African context (Hirschmann 1990: 4). This follows from the historical fact that racial distinctions were (and in many ways, still are) the central basis for social and cognitive organisation, spatial demarcation, economic distribution, and legal and political governance in 'South Africa' and much of the modern world. Indeed, since the advent of European domination in Africa, the very definitions of personhood and humanity have been racially determined categories (Mills 2014: 33). Biko's critique of white liberals, his rejection of the Marxist privileging of class over race, his much-critiqued silence on questions of gender and sexuality, and most importantly, his location of racism in the collective group power of dominant 
racial group (whites) and its will to subjugate its racial Others all flow from his concept of the totality of white power and the analytical and political primacy he accords to race or what he calls 'the colour problem'.

If the Azanian conception of race/ism, because of its fidelity to the larger global black radical tradition and key tenets of critical race theory, has not been entirely superseded by current developments in global Black and emancipatory thought across the human and social sciences, it certainly now has to take greater cognisance of these developments, particularly, the currents of debates within and between Black Marxism, Black feminism, Afropessimism, and Black Male Studies and their impact on 'South African' scholarship. In particular, attention will need to be paid to the development of an Azanian theory of gender and sexuality and an Azanian theory of political economy among others through an African-centred historical and cultural paradigm.

\section{(c) African Culture, History, Experience, and Imagination as the Basis for Knowledge Production and Liberation}

The Azanian tradition has historically upheld a consistent repudiation of multiracial collaboration (especially with white liberals and leftists) and cooperation with the state and white paternalism mainly because they harboured benign forms of racial domination and risked subordinating the liberation struggle to non-African interests. The militant turn to mass mobilisation of the oppressed initiated by the founding actors of the Azanian tradition similarly marked a resistance against the capture of the liberation struggle by elite powers and interests (Gerhart 1978: 129). As they argued, 'the only way in which domination will ever be broken is by a black force' (ibid.: 163). Thus, the praxis and pedagogy of the Africanists and Black radicals of the Azanian tradition stressed the values of self-reliance, unity, humanness, and self-determination - which extended not only to political sovereignty but intellectual sovereignty as well. If Black people are to lead and direct their own struggles and be their own liberators, they needed to first cultivate a disalienated consciousness, which in turn required that they critically apprehend their condition and reality on their own terms.

For the Africanists and black radicals of Azania, the main philosophical and cultural source of the liberation struggle and the 
primary knowledge system from which paradigms of law, social organisation, political ordering, religious, cultural and educational practices and institutions, ecology, aesthetics, and moral norms for a liberated society would be the unfolding and evolving African historical experience. The sum-total long memory and lessons of African people's existence in the world, including the cultures, languages, cosmologies and spiritualities, knowledges, ways of life, norms, and practices birthed from within the African life-world from antiquity to the present, and constantly evolving and adapting to changing circumstances and environments constitute this historical experience. The need to study and embrace the great African civilisations and kingdoms as well as the great heroes and heroines of the long African liberation struggle (Gerhart 1978: 200-201) is a necessary component of the Azanian philopraxis. This is not only to build the self-knowledge and will of the African personality but also to be mined as a source for constructing knowledge for liberation and for the practical resolution of the historical and social predicaments resulting from the global European disintegration of the African social and cultural reality and the attendant disasters of capitalist modernity now facing the world. Here there is no assumption of a perfect African past as Lembede also called for the 'bitter and painful' aspects of African culture and history to be acknowledged in this endeavour (ibid.: 59). There is also no inward retreat to an own or pure world - again Lembede is emphatic that the work of building a liberated African future would be intercultural, borrowing the best of Western and Eastern cultures suitably adapted to the African context (ibid.: 64). What the Azanian tradition does decry and renounce is 'superficial or artificial mimicry [of other cultures] with no social roots' (ibid.), the wholesale 'importing of foreign ideologies into Africa' (ibid.: 65), and the 'one-way absorption' of Western and 'white' cultural standards (ibid.: 66).

The rejection of integrationist, assimilationist, and reformist visions that is at the heart of the Azanian philosophy of liberation was based on the critique that integration or assimilation fails to dismantle the colonial-apartheid social order which was built upon the assumed superiority of the civilisation, paradigms, institutions, and onto-epistemes of the conqueror and thus, in essential ways, perpetuated political and economic but also more profoundly epistemic bondage. Both colonial conquest and integrationist and 
assimilationist visions force Black people to live in worlds not of their making or imagining - worlds constituted by their negation. Relatedly, the critique of white liberals and leftists that was repeatedly voiced by proponents of Africanism and Black Consciousness went beyond the political problem of white paternalism and incorporated a conceptual and ideological critique of the cultural assumptions and philosophical anthropology of white intellectual and political traditions such as liberalism (including Western liberal feminism) and Marxism. This critique took off from the significant fact that both liberalism and Marxism emerged from within the alien and particular historical context and experience of Europe.

In the case of liberalism, it was its racialised illiberal underside and the falsity of its universalist and humanist conceits which associated progress and civilisation with whiteness and Western values that made it unsuitable to the struggle for African and Black liberation (Gerhart, 1978: 7). In the case of Marxism, it was its subordination of race to class as well as its denial of the spiritual element of human existence that made it the object of Azanian critique (ibid.: 55). In a word, the Azanian antipathy towards liberalism and Marxism was ultimately not about the predominance of their white proponents or even their Western origins but their conceptual deficiencies which, from an Azanian perspective, led to their misdiagnosis or definition of the social and historical reality of 'South Africa' - incorrect largely for their failure to foreground the materiality of race, white supremacy, and settler-colonialism (ibid.: 158). De-linking from these Western epistemological and cultural frameworks calls for a form of African cultural and intellectual reassertion very much akin to Amilcar Cabral's notion of 're-Africanisation' or 'return to the source' (see in particular Cabral 1978: 146) and Ngugi wa Thiongo's formulation of decolonisation as the 're-centering' of Africa (1986: 94). Recall here Biko's strident protest:

I am against the superior-inferior white-black stratification that makes the white a perpetual teacher and the black a perpetual pupil (and a poor one at that). I am against the intellectual arrogance of white people that makes them believe that white leadership is a sine qua non in this country and that whites are the divinely appointed pace-setters in progress. I am against the fact that a settler minority should impose an entire system of values on an indigenous people. (Biko 2012: 29) 
For Biko, the broad direction of a liberated Azania must 'inevitably exhibit African values and be truly African in style' (parenthetically, it is in such moments where Biko's assumed departure or distinction from the Africanists appears to be overstated) (ibid.: 26). The philosophical value of ubuntu and its capacity to give 'the world a more human face' (ibid.: 47) is at the heart of Biko's critique of the individualistic, exploitative, and materialistic values of Western culture (ibid.: 44-45). Africa is also at the centre of his vision for liberation, which for him is neither about turning of the tables or seeking a place at the table but rather radically reconstituting the table. As he writes:

We knew he had no right to be there; we wanted to remove him from our table, strip the table of all trappings put on it by him, decorate it in true African style, settle down and then ask him to join us on our own terms if he liked. (ibid.: 75)

\section{Azanian Prophecies - Against the 'Post'-Apartheid}

Black radicalism is the negation of Western civilisation. (Robinson 1983: 72)

It bears repeating that this narration of Azanian thought in terms of the political evolution and movement of Africanism and Black Consciousness orbiting principally around the figures of Lembede, Sobukwe, and Biko is only one partial account of a larger, longer, and more complex historical and political archive whose depths are yet to be plumbed. An important biographical point in the intellectual history of these three extraordinary figures is of course that on account of the early deaths of Lembede (33) and Biko (30) and the captive life of Sobukwe, who from the age of 36 was incarcerated and then later subjected to internal exile and state repression until his death, the archive of Azanian thought is necessarily incomplete and inchoate. It rests with a new generation of intellectuals to take on the labour of retrieving, elaborating, and deepening these ideas and visions in new directions. The preceding intervention offered a synthesis of the main ideas of Azanian thought that could provide a basis for the construction of a radical social theory to rethink and upend knowledge of and about 'South Africa' across the spectrum 
of the human and social sciences as well as in popular public discourse consciousness. The recurring thematic and impulse of abolition - the abolition of the colonial state, the abolition of 'South Africa', the abolition of (the myth of) race; the abolition of white supremacy and by extension, the abolition of the present South African constitution - that runs across the Azanian tradition presents a most subversive and capacious starting point for Black radical thought in the post-1994 milieu.

This reassertion of the Azanian political and intellectual tradition in post-1994 'South Africa' redraws anew the enduring historical antinomy between two strains in Black emancipatory thought or two Black political cultures. These are the liberal anticolonialist tradition (the 'realists') centred on political accommodation and integration into a common South African identity shaped by Western civilisation (in the South African context represented by the Congress or Charterist tradition of the ANC) and the radical anti-colonial tradition (the 'rebels') which centred on reclaiming political and cultural sovereignty, reconquest of the land and a fundamental re-ordering of the institutions and values governing society (represented by the Azanian tradition) (Fredrickson 1995: 12; Gerhart 1978: 39-44; Soske 2018: 68-69; Fatton 1986: 3-8; Halisi 1999: 4-8, 110-131). Whereas the Azanian tradition sought to resist and dismantle the settler-created racial polity, the Charterist/Congress tradition sought to negotiate for and demand equitable and democratic incorporation into it. This distinction is of great intellectual, political, and ethical significance and pertains to the divergent horizons of desire and possibility that shaped the Charterist/Congress and Azanian political traditions respectively. It cannot simply be reduced to Realpolitik or crude pragmatism.

It is by now a hardly controversial observation that it was the vision and telos of the Congress Tradition that gained international prominence in the anti-apartheid years and ultimately determined the path of the transition to the (second) 'new South Africa'. Indeed, the dominant conceptions of history, law, justice, political community and nationhood, social and economic organisation that enframe 'South Africa's' post-1994 constitutional democracy derive their most essential elements from the mythology of the Congress Tradition as it unfolded throughout the twentieth-century. From its 
emergence in the 1940s within the ANC and its ultimate break from the ANC in the late 1950s, the Azanian perspective shows us that the 'new South Africa' derives its heritage from political and legal actors who generally acceded to their colonial status; accepted the terms of the colonialist discourse (especially its concept of race and its definition of civilisation through Western culture and Western political economy) and historically adopted a moderate and reformist orientation to anti-colonial and anti-apartheid struggle - an orientation heavily influenced by white fears and anxieties(Gerhart 1978: 94, 150; Karis and Gerhart 2013: 121).

By the end of the 1950s, the cunning and tragedy of settler-colonial reason had crystallised in the realisation by the Africanists that the perfection of colonial conquest was to be generated from within the Congress Tradition and its principal document, the Freedom Charter (Raboroko 1960; Tafira 2016: 294-295). In the Azanian perspective, the multinational, multiracial society, state capitalist and liberal social democracy outlined in the Freedom Charter amounted to an egalitarian adjustment (that is, transformation) and at the same time preservation of the racialised socio-political and cultural order entrenched through colonial dispossession, violence, and racial subjugation (including the subjugation of African sovereignties) (Tafira 2016: 294-295).

The Freedom Charter's main pillar and leading declaration that 'South Africa belongs to all who live in it' performs a crucial historical erasure and obfuscation of the fact of the dispossession of indigenous land and labour and colonial settlement. In this way, it also reflects what has been described as the amnesiac character of settler-colonialism in its 'persistent drive to supersede the conditions of its operation' (Veracini 2011: 3) and to 'make itself [appear] invisible, natural, without origin (and without end), and inevitable' (Tuck and Yang 2014: 228-222). The Africanist critique of the Charter as antithetical to freedom and independence (Raboroko 1960: 32) lives on due to the fact that the famous declaration previously mentioned was also included in the preamble of the 1996 South African constitution, thereby extending the 'right of conquest'. The historical details on this point are the subject of heated (and possibly irresolvable) debate and contestation and there is insufficient space in this article to engage them here. 
What is important for the argument at this stage is to underscore that the Azanian view was that the Congress tradition's answer to the 'National Question', its overall philosophy and strategy of anti-colonial and anti-apartheid struggle leading into the 'new' South Africa, was both ethically untenable and politically unjust but also, and most important, practically unsustainable in the long-term.

In the context of jurisprudence in the afterlife of colonial-apartheid, the challenge posed by the Africanist and Black radical traditions has been translated into an abolitionist and decolonisation critique of the present 1996 constitution. This critique itself is a response to the continuity and persistence of racially determined social divisions and power relations which bring into question the political temporality that designates the present 'South Africa' as substantively 'post-apartheid'. Constitutional abolitionism is also a response to the prevailing discourse of constitutional optimism or 'transformative constitutionalism' and its monumentalising celebration of the democratic transition as well as its casting of the constitutional text as the supreme juridical rationality, moral lodestar, and political blueprint of and for 'South Africa'. Scholars associated with the decolonisation or abolitionist critique have drawn on the Azanian tradition to issue a three-fold challenge to this position, arguing instead that the post-1994 constitution: (1) is an evolutionary legal, political, and epistemic rearrangement of 'white South Africa' - an adjustment or 'makeover' (democratisation) rather than a fundamental rupture (decolonisation); (2) sustains colonial logics of state formation, political economy and racialisation and upholds the erasure of African cosmologies, legalities, and epistemologies; and (3) ultimately naturalises and normalises the settler-created world (or the conqueror's South Africa) as the only possible world (see, generally, Ramose 2001; Ramose 2007; Madlingozi 2017; Dladla 2018; Modiri 2018).

This critique in not invested in the question of whether the constitution contains the potential - through augmented implementation and interpretation - to ameliorate historical injustices and inequalities but rather attends to the failure of the constitution to terminate the settler-colonial foundations through which those disadvantages and inequalities were produced and perpetuated. Or put differently, 
this is a critique which measures the value and progress of the constitution in terms of a much more expansive account of historical injustice and a much wider vision of liberation. Constitutional abolitionism interrogates the present constitution in terms of its impact on the social and political foundations of society - not at the level of the circumstances of individuals or groups of individuals (such as court litigants and social movements) but rather at the level of the historical structures of society. ${ }^{20}$

The key contention here is that rather than accommodate old orders of power and old subject-positions, the Azanian tradition envisaged that the liberation struggle would produce not only a new polity, new social relations of belonging, and a new economic system and cultural values, but also that it would in the process forge a new historical subject. When neither a radically new polity nor a new historical subject emerges in the process of a political and legal transition, a deep inertia sets in akin to an untreated or poorly treated wound becoming septic. As the historical record attests, the adoption of the 1996 constitution consolidated the defeat of the Azanian tradition and of anti-colonial and Black radical intellectual and political frameworks in the academy. This in turn gives the reemerging Africanist and Black Consciousness-based scholarship a prophetic and haunting quality.

The Azanian critique of Charterism, liberal multiracialism, and integration read very much as warnings for a future society that would not listen. It was especially Biko who most directly and clearly anticipated the problem of an empty and unliberated future (Mngxitama et al. 2008: 12). In his prophetic moments, Biko gestured to the problematics of a 'post-1994' society that would remain structured by the colonial-apartheid status quo (Mngxitama et al. 2008 2, 4, 12, 17). It was Biko who foresaw that if 'South Africa' followed the path of 'hastily arranged integration' - in which the 'slave [would be expected] to work together with the slave-master's son to remove all the conditions leading to the former's enslavement' - this could only result in a re-elaboration of Black people's unemancipated condition (Biko 2012: 22). This remains his most prophetic utterance:

If we have a mere change of face of those in governing positions what is likely to happen is that black people will continue to be poor, and you 
will see a few blacks filtering through into the so-called bourgeoisie. Our society will be run almost as of yesterday. (Biko 2012: 169)

\section{Conclusion: The End(s) of South Africa}

The recreation of African and diaspora history must become part of the recreation of Black life. (Robinson 1996: 75)

Blackness is theory itself. (Gordon cited in Sexton 2012)

The political challenge posed by the Azanian tradition to the stability and coherence of 'South Africa' as a territory, polity, and idea is an intellectual one as well. The invocation of Azania opens and claims a space for Africanist and Black radical voices and perspectives in an academy that for too long has been over-determined by liberal consensus and Eurocentrism. While there is much more to be unpacked about the conditions of possibility for the historical development and philosophical assumptions of the Africanist and Black Consciousness movements in 'South Africa', the argument posited in this article is that they enable us to build new categories, problems and questions (and to re-interpret or fracture old ones) in the historical, social, cultural, political, and legal study of 'South Africa'. This article thus reads Azania as an intellectual tradition, political movement and a moral and cultural sensibility formed from within the community of the conquered that could serve as the foundation for new directions in oppositional and emancipatory theory and politics. The main aim of this project is to analytically recentre and foreground the historical (and still enduring) problematics of race, conquest, settler-colonialism, and white supremacy in how we theorise and experience the present South African, African, and global conjunctures. As such, this is a project of politically engaged scholarship that nevertheless maintains the dream of rigour or at least depth - deep study and deep questioning.

Azania and Azanian thought poses to us the question of how to decentre and unthink the name, territory, and formation of 'South Africa' as we know it in a climate where virtually all academic and public discourse takes its legitimacy, coherence, and permanence for granted. Yet the ethical challenge of the Azanian tradition is precisely that every affirmation of 'South Africa' disavows its origins 
in colonial invasion and violence and thus redraws and compounds the historical antagonism. As I have attempted to roughly sketch in this article, the Azanian vision for a new sociality and polity and its grammar of post-conquest futurity begins at the end of 'South Africa' and on the ruins of the post-'apartheid'. This is a beginning which calls us - scholars, activists, creative workers, Black people, everyone - to confront once more our unbearable historical ordeal.

\section{Acknowledgements}

This piece was written during a visiting fellowship at Oxford University under the auspices of the Africa Oxford Initiative and the Oxford Law Faculty. My thanks to Anne Makena and Helen Scott for hosting my visit - and most especially to Nomfundo Ramalekana for edifying and stimulating debate and conversation on the issues set out in this piece. Thanks also to Ndumiso Dladla and Sanele Sibanda for engaging this piece as part of our larger struggle for reason in Africa, South.

Joel Modiri is associate professor and head of the Department of Jurisprudence at the University of Pretoria. He is currently engaged in a book project on Black Consciousness as a critique of postapartheid political rationality. E-mail: joel.modiri@up.ac.za https://orcid.org/0000-0001-6806-8261

\section{Notes}

1. In this article and depending on the context, the label African will be used in reference to the indigenous conquered peoples in "South Africa", inclusive of the Khoi, San, and Bantu-speaking communities as well as their progeny through interracial crossing. The category Black also refers to the conquered peoples of South Africa (African and 'Coloured' peoples) but also includes the Indian population. While the Indian population cannot be classified as indigenous, they were also subjected to racial oppression and subjugation under colonial and apartheid rule. This formulation of blackness is derived from the Black Consciousness Movement as it sought to expand the category of the oppressed to include Africans (indigenous) and other racially oppressed non-indigenous groups under one unifying political identity.

2. The notion of the 'post-conquest' is derived from the work of Mogobe Ramose. See his 'Towards a Post-conquest South Africa: Beyond the constitution of 1996', South African Journal on Human Rights 34, no. 3 (2018): 326-341. 
3. It might be useful to distinguish between 'the long Azanian tradition' (which begins at the moment of the colonial encounter with the anticolonial wars of resistance waged by communities of indigenous conquered peoples in territories that now make up South Africa) from the specific articulation of an Azanian social and political philosophy in the twentieth century by activist intellectuals in the ANC Youth League of the 1940s and then most clearly by the Pan-Africanist Congress and Black Consciousness Movement and their intellectual and political progeny. The term 'Azania' itself was introduced by the PAC in 1965.

4. The two scholars associated with the most vociferous version of these critiques are: Kwame Anthony Appiah, In My Father's House: Africa in the Philosophy of Culture (Oxford: Oxford, 1992); and Achille Mbembe, 'African Modes of SelfWriting', Public Culture 14, no. 1 (Winter 2002): 239-273.

5. For one account, see A. Mafeje, 'White Liberals and Black Nationalists: Strange Bedfellows', Africa Review 11, no. 13 (December 1998): 45-48.

6. I have previously written on this in 'Conquest and Constitutionalism: First Thoughts on an Alternative Jurisprudence', South African Journal on Human Rights 34, no. 3 (2018): 308-323.

7. While they possess a generative conceptual utility and resonance with the present endeavor, both settler-colonial studies and US Black studies (and specifically the pathbreaking theory of Afropessimism) are structured by categories that cannot always be neatly reconciled to the South African socio-historical context where the African majority embodies a meeting point between blackness and indigeneity as historical properties.

8. The work and orientation of Cedric Robinson is pivotal to this undertaking. See in particular his Black Marxism: The Making of the Black Radical Tradition (University of North Carolina Press: Chapel Hill, 1983); 'Notes Toward a 'Native' Theory of History', Review 4, no. 1 (Summer 1980): 45-78; 'In Search of a Pan-African Commonwealth', Social Identities 2, no. 1 (1996): 161-168.

9. I have adopted 'African humanness' as a shorthand to describe the philosophy of ubu-ntu/bo-tho. For a fuller exposition of its meaning and implications, see Mogobe Ramose, African Philosophy through Ubuntu (Mond Books: Harare, 1999).

10. Zuberi and Bonilla-Silva 2008, 15-17. See also Charles Mills, 'Non-Cartesian Sums: Philosophy and the African-American Experience', Teaching Philosophy 17, no. 3 (1994): 223-243, and 'An illuminating Blackness', The Black Scholar 43, no. 3 (2013): 32-37 for the view that the racial identity of the philosopher/theorist/ scholar affects 'the array of concepts found useful, the set of paradigmatic dilemmas, the range of concerns' that shape one's intellectual and political work. For Mills, racial identity (understood here as subject positioning and socialisation as a raced person) also affects how one interprets particular theories and the political and ideological position(s) one adopts.

11. George Fredrickson, White Supremacy. A Comparative Study in American and South African History (Oxford University Press: New York, 1981), 189-190, explains this as the distinction between 'teleological racism' (the theory generally held by the Afrikaner Nationalists that blacks are inherently and naturally inferior and thus had been created to serve, and be enslaved by, their white masters) and 'evolutionary racism' (a view informed by the post-Enlightenment liberalism of the English which accepted black people's perceived ontological inferiority as a starting point but argued that this was not immutable and that it was possible for uncivilized and underdeveloped peoples to be gradually elevated into civilization). Similarly, David Theo Goldberg, The Racial State (Blackwell: Malden, 2002), 74-80, develops the corresponding distinction between 'racial naturalism' (positing the irretrievable inferiority of the non-European) and 'racial historicism' 
(promising racial inclusion into European definitions of the human as a remedy for the civilisational immaturity of the non-European). These modalities of racial thought are no longer expressed as openly as they once were. They nonetheless linger and reverberate at the foundations of all academic disciplines and civil society in South Africa.

12. There are, of course, exceptions to this point, but the overall provocation remains that race (and especially race theorised from the lens of Black critique) suffers from hesitant and tangential treatment in South Africa as compared against its sheer ubiquity and social and psychic weight in South African history. Either it is approached with complete silence or suspicion or by way of a deficient, ahistorical, and foreign conceptual apparatus (liberal individualism, Charterist multi-racialism, Marxism, postructuralism). Marzia Milazzo, for example, has studied how the reproduction of colourblind discourse in the South African academy functions as a 'rhetoric of racial power' and is 'emblematic of an investment in maintaining' racialised inequality, power, and privilege. See Marzia Milazzo, 'The Rhetorics of Racial Power: Enforcing Colorblindness in Post-Apartheid Scholarship on Race', Journal of International and Intercultural Communication 8, no. 1 (2015): 7.

13. See, generally, Charles Mills, The Racial Contract (Cornell University Press: Ithaca, 1997); Sylvia Wynter, 'Afterword: Beyond Miranda's Meanings: Unsilencing the 'Demonic Ground' of Caliban's Women', in Carol Boyce Davies and Elaine Savory Fido (eds), Out of the Kumbla: Caribbean Women and Literature (Africa World Press: Trenton NJ, 1990), 355-372.

14. David Theo Goldberg, The Threat of Race: Reflections on Racial Neoliberalism (Blackwell: Malden, 2009), 21: 'If antiracist commitment requires remembering and recalling, antiracialism suggests forgetting, getting over, moving on, wiping away the terms of reference ... '. Goldberg continues (at 22): 'As an end in itself, antiracialism it turns out for the most part, is whiteness by another name'.

15. As Robert Ross (2008: 112) writes in respect of the Union of South Africa in the early twentieth century: 'The corollary of white South African nationalism . . . was the exclusion of blacks from the body politic and their permanent subordination'.

16. Henkes (2016: 641-669) writes of this period (at 645): 'whiteness was always defined against blackness. The absence of blacks [from the 1921 census and other State policies] shows that white supremacy was thought essential, despite internal frictions amongst the white population'. Magubane reaches the same conclusion: 'The English and Afrikaner ruling classes never allowed their quarrels to disrupt the racial order of white supremacy' (2000: 50).

17. This is what distinguishes the Azanian conception of race from the radical left racedenialism of dominant currents of the Non-European Unity Movement (NEUM). See Soske 2015: 23.

18. Whether these racial divisions are more precisely theorised in terms of the carving up of humanity and the dehumanisation of the Black, or rather as the excision or expulsion of the Black from the category of Human, remains to be studied in greater detail in future writing.

19. See, for example, Ross, A Concise History of South Africa, 135 (reporting that the Charter was 'primarily drafted' by Lionel 'Rusty' Bernstein); and A. Wielder, Ruth First and Joe Slovo in the War Against Apartheid (New York: Monthly Review Press, 2013) (crediting Ruth First for 'organiz[ing] the ideas of the people' (at 88) and naming First and her partner, Joe Slovo as among those responsible for 'writing' the Charter). While space does not permit further discussion here, the problem that whites in particular wielded such substantial and disproportionate intellectual and organizational influence in the struggle for black liberation (even before formal admission of whites into the membership of the ANC) and seemed to be authoritative voices in the formulation of both revolutionary political theory 
and strategy as well as the early ideas on constitution-making in the Congress Alliance remains a bone of serious ethical, historical, and political contention from an Azanian perspective. Of particular concern is the role of white leftists in the larger assault on African nationalism and black radicalism. Consider, for example, the case of First who in the late 1950s is said (Wielder 2013: 107) to have directed much 'venom' towards the PAC - to the point of deploying her editorial powers at the New Age newspaper to celebrate their break away from the ANC with the headline 'Good Riddance'.

20. To be sure, constitutional abolitionism is an analytic of liberation that directs its critical energies towards and against the succession of conqueror constitutional frameworks. It is not, indeed cannot be, a rejection of the idea of constitutionalism as the coming together, deciding together and standing together of a community. At the same time, the object of abolition in the final instance is conqueror South Africa and not merely the constitutional text.

\section{References}

Appiah, K. A. 1992. In My Father's House: Africa in the Philosophy of Culture. Oxford: Oxford University Press.

Beinart, W. 2001. Twentieth Century South Africa, 3. Oxford: Oxford University Press.

Biko, S. B. 2012 (1978). I Write What I Like: A Selection of His Writings. Johannesburg Picador Africa.

Boahen, A. A. (ed). 1990. UNESCO General History of Africa Volume VII: Africa Under Colonial Domination 1880-1935. Berkeley: University of California Press.

Cabral, A. 1978. 'National Liberation and Culture'. In Unity and Struggle: Speeches and Writings of Amilcar Cabral. New York: Monthly Review Press. $138-156$.

Comaroff, J. L. 1998. 'Reflections on the Colonial State, in South Africa and Elsewhere: Factions, Fragments, Facts and Fictions', Social Identities 4 (3): 321-361. doi: 10.1080/13504639851663

Curry, T. J. 2011a. 'The Derelictical Crisis in African American Philosophy: How African American Philosophy Fails to Contribute to the Study of African Descended Peoples', Journal of Black Studies 42 (3) 314-333. doi: $10.1177 / 0021934710367899$

Curry, T. J. 2011b. 'On Derelict and Method: The Methodological Crisis in Africana Philosophy's Study of African Descended Peoples under an Integrationist Milieu', Radical Philosophy Review 14 (2): 139-164. doi: 10.5840/radphilrev201114216

da Silva, F. 2018. 'Hacking the Subject: Black Feminism and Refusal beyond the Limits of Critique', PhiloSOPHIA 8 (1): 19-41. doi: 10.1353/ phi.2018.0001

Dladla, N. 2017. 'Contested Memory - Retrieving the Africanist (Liberatory) Conception of Non-Racialism', Theoria 64 (4): 101 - 127. 
Dladla, N. 2018. 'The Liberation of History and the End of South Africa: Some Notes towards an Azanian Historiography in Africa, South', South African Journal of Human Rights 34 (3): 415-440. doi: 10.1080/02587203.2018.1550940

Fatton, R. 1986. Black Consciousness in South Africa: Dialectics of Ideological Resistance to White Supremacy. Albany, NY: SUNY Press.

Fredrickson, G. M. 1981. White Supremacy. A Comparative Study in American and South African History. New York: Oxford University Press.

Fredrickson, G. M. 1995. Black Liberation: A Comparative History of Black Ideologies in the United States. New York: Oxford University Press.

Furedi, F. 1999. The Silent War: Imperialism and the Changing Perception of Race. New Brunswick, NJ: Rutgers University Press.

Gerhart, G. 1978. Black Power in South Africa: Evolution of an Ideology. Berkeley: University of California Press.

Getachew, A. 2019. Worldmaking after Empire. Princeton: Princeton University Press.

Goldberg, D. T. 2002. The Racial State. Malden: Blackwell.

Goldberg, D. T. 2009. The Threat of Race: Reflections on Racial Neoliberalism. Malden: Blackwell.

Gordon, L. R. 2006. 'African-American Philosophy, Race and the Geography of Reason'. In L. R. Gordon and J-A. Gordon (eds), Not Only the Master's Tools: African-American Studies in Theory and Practice. New York: Routledge. 85 - 106.

Gordon, A., and Newfield, C. 1994. 'White Philosophy', Critical Inquiry 20 (4): 737-757. https://www.jstor.org/stable/1343857

Halisi, C. R. D. 1999. Black Political Thought in the Making of South African Democracy. Bloomington: Indiana University Press, 110-131.

Hallett, R. 1974. Africa Since 1875. London: Heinemann.

Henkes, B. 2016. 'Shifting Identifications in Dutch-South Africa Migration Policies (1910-1961)', South African Historical Journal 68 (4): 641-669. doi: 10.1080/02582473.2016.1188977

Hirschmann, D. 1990. 'The Black Consciousness Movement in South Africa', Journal of Modern African Studies 28 (1): 1 - 22.

Hudson, P. 2013. 'The State and the Colonial Unconscious', Social Dynamics 39 (2) (2013): $263-277$.

Karis, T. G. and Gerhart, G. 2013. From Protest to Challenge: A Documentary History of African Politics in South Africa 1882 - 1990: Vol 3 Challenge and Violence, 1953 - 1964. Johannesburg: Jacana Press.

Keegan, T. 1996. Colonial South Africa and the Origins of the Racial Order. Charlottesville: University of Virginia Press.

Kelley, R. D. G. 2017. 'The Rest of Us: Rethinking Settler and Native', American Quarterly 69 (2): 267-276. doi: 10.1353/aq.2017.0020

Madlingozi, T. 2017. 'Social Justice in a Time of Neo-apartheid Constitutionalism: 
Critiquing the Anti-black Economy of Recognition, Incorporation and Distribution', Stellenbosch Law Review 28 (1): 123-147.

Mafeje, A. 1998. 'White Liberals and Black Nationalists: Strange Bedfellows', Africa Review 11 (13): 45-48.

Magubane, B. M. 1986. 'The Political Economy of the South African Revolution', African Journal of Political Economy 1 (1): 1-28.

Magubane, B. M. 1996. The Making of a Racist State: British Imperialism and Union of South Africa 1875-1910. Trenton, NJ: Africa World Press.

Magubane, B. M. 2000. 'Race and Democratization in South Africa', Macalaster International 9 (1): 33-82.

Mamdani, M. 1998. 'When Does a Settler Become a Native? Reflections on the Colonial Roots of Equatorial and South Africa', Inaugural lecture as AC Jordan professor of African Studies. Cape Town: University of Cape Town. https://citizenshiprightsafrica.org/wp-content/uploads/1998/05/mamdani1998-inaugural-lecture.pdf

Mbembe, A. 2002. 'African Modes of Self-Writing', Public Culture 14 (1): 239-273.

Milazzo, M. 2015. 'The Rhetorics of Racial Power: Enforcing Colorblindness in Post-Apartheid Scholarship on Race', Journal of International and Intercultural Communication 8(1): 7-26. doi: 10.1080/17513057.2015.991075

Mills, C. W. 1994. 'Non-Cartesian Sums: Philosophy and the AfricanAmerican Experience', Teaching Philosophy 17 (3): 223-243. doi: 10.5840/ teachphil199417327

Mills, C. W. 1997. The Racial Contract. Ithaca: Cornell University Press.

Mills, C. W. 1998. Blackness Visible: Essays on Philosophy and Race. Ithaca, NY: Cornell University Press.

Mills, C. W. 2003. 'White Supremacy as a Socio-political System'. In A. W. Doane and E. Bonilla-Silva (eds), White Out: The Continuing Significance of Racism. New York: Routledge. 35-48.

Mills, C. W. 2013. 'An illuminating Blackness', The Black Scholar 43 (3): 32-37. doi: 10.5816/blackscholar.43.4.0032

Mills, C. W. 2014. 'Materializing Race'. In E. S. Lee (ed), Living Alterities: Phenomenology, Embodiment and Race. Albany, NY: SUNY Press.

Mngxitama, A., Alexander, A., and Gibson, N. 2008. 'Biko Lives'. In A. Mngxitama, A. Alexander, and N. Gibson (eds), Biko Lives! Contesting the Legacies of Steve Biko. New York: Palgrave.

Modiri, J. M. 2018. 'Conquest and Constitutionalism: First Thoughts on an Alternative Jurisprudence', South African Journal on Human Rights 34 (3): 308-323. doi: 10.1080/02587203.2018.1550939

Pierre, J. 2013. The Predicament of Blackness: Postcolonial Ghana and the Politics of Race. Chicago: University of Chicago.

Pillay, S. 2009. 'Translating 'South Africa': Race, Colonialism and Challenges of Critical Thought after Apartheid'. In H. Jacklin and P. Vale (eds). 
Re-imaging the Social in South Africa: Critique, Theory and Post-apartheid Society. Durban: KwaZulu-Natal Press, 235-267.

Pillay, S. 2015. 'Why I am No Longer a Non-racialist: Identity and Difference'. in X. Mangcu (ed), The Colour of our Future: Does Race Matter in Postapartheid South Africa. Johannesburg: Wits University Press. 133 - 152.

Raboroko, P. N. 1960. 'Congress and the Africanists: The Africanist Case', Africa South 4.

Ramose, M. B. 2000. “African Renaissance”: A Northbound Gaze', Politeia 19 (3): 47-61.

Mogobe Ramose, M. B. 2001. 'An African Perspective on Justice and Race', Polylog 3: http://them.polylog.org/3/frm-en.htm.

Ramose, M. B. 2003. 'I Conquer Therefore I am the Sovereign: Reflections Upon Sovereignty, Constitutionalism and Democracy in Zimbabwe and South Africa'. In P. H. Coetzee and A. P. J. Roux (eds), The African Philosophy Reader. London: Routledge, 544.

Ramose, M. B. 2007. 'In Memoriam: Sovereignty and the 'New' South Africa', Griffith Law Review 16 (12): 310-329.

Ramose, M. B. 2018. 'Towards a Post-conquest South Africa: Beyond the constitution of 1996', South African Journal on Human Rights 34 (3): 326341. doi: 10.1080/02587203.2018.1550937

Robinson, A. M. 2015. The White Possessive-Property, Power and Indigenous Sovereignty. Minneapolis: University of Minnesota Press.

Robinson, C. J. 1980. 'Notes Toward a 'Native' Theory of History', Review (Fernand Braudel Center) 4 (1): 45-78.

Robinson, C. J. 1983. Black Marxism: The Making of the Black Radical Tradition. Chapel Hill: University of North Carolina Press.

Robinson, C. J. 1996. 'In Search of a Pan-African Commonwealth', Social Identities 2 (1): 161-168. doi: 10.1080/13504639652439

Ross, R. 2008. A Concise History of South Africa. 2nd edition. Cape Town: Cambridge University Press.

Sexton, J. 2012. 'Ante-Anti-Blackness: Afterthoughts', Lateral 1. doi: 10.25158/ L1.1.16

Sobukwe, R. M. 1959. 'The Opening Address at the Africanist Inaugural Convention', 4 April 1959. https://www.sahistory.org.za/archive/document58-robert-mangaliso-sobukwe-opening-address-africanist-inauguralconvention-4

Soske, J. 2015. 'The Impossible Concept: Settler Liberalism, Pan-Africanism, and the Language of Non-racialism', African Historical Review 47 (2): $1-26$.

Soske, J. 2018. Internal Frontiers: African Nationalism and the Indian Diaspora in Twentieth-Century South Africa. Johannesburg: Wits University Press.

Tafira, H. K. 2016. Black Nationalist Thought in South Africa: The Persistence of an Idea of Liberation. New York: Palgrave Macmillan. 
Tuck, E. and Yang, K. W. 2014. 'R-Words: Refusing Research'. In D. Paris and M. T. Winn (eds), Humanizing Research: Decolonizing Qualitative Inquiry with Youth and Communities, Thousand Oaks, CA: SAGE.

Veracini, L. 2011. 'Introducing Settler Colonial Studies', Settler Colonial Studies 1 (1): 1-12. doi: 10.1080/2201473X.2011.10648799

wa Thiong'o, N. 1986. Decolonising the Mind: The Politics of Language in African Literature. London: Heinemann.

Webster, A. 2018. 'On Conquest and Anthropology in South Africa', South African Journal on Human Rights 34 (3): 398-414. doi: 10.1080/02587203.2018.1543840

Wielder, A. 2013. Ruth First and Joe Slovo in the War Against Apartheid New York: Monthly Review Press.

Wynter, S. 1990. 'Afterword: Beyond Miranda's Meanings: Unsilencing the 'Demonic Ground' of Caliban's Women'. In C. B. Davies and E. S. Fido (eds), Out of the Kumbla: Caribbean Women and Literature. Trenton, NJ: Africa World Press, 355-372.

Wynter, S. 1995. '1492: A New World View'. In V. L. Hyatt and R. Nettleford (eds), Race, Discourse and the Origin of the Americas-A New World View. Washington: Smithsonian Institution Press, 5-57.

Zuberi, T. and Bonilla-Silva, E. 2008. 'Toward a Definition of White Logic and White Methods'. In T. Zuberi and E. Bonilla-Silva (eds), White Logic, White Methods: Racism and Methodology. Lanham: Rowman and Littlefield. 3 30. 